\title{
MANAJEMEN KEPEMIMPINAN SERTA KORELASINYA TERHADAP MOTIVASI DAN KINERJA KARYAWAN STMIK BAHRUL ULUM TAMBAKBERAS JOMBANG
}

\author{
Muhyiddin, Z.A \\ STMIK Bahrul 'Ulum Tambakberas Jombang
}

\begin{abstract}
Abstraksi
Peran Pemimpinan Terhadap Motivasi dan Kinerja Karyawan STMIK Bahrul 'Ulum Jombang kadang ditemukan masalah yang banyak dihadapi oleh lembaga. Di STMIK Bahrul 'Ulum juga menghadapi hal yang sama. Pada penelitian yang menggunakan analisis jalur dengan hasil sebagai berikut: 1). perhatian pimpinan pada bawahan (X1) berpengaruh secara positif dan signifikan terhadap kinerja karyawan (Y) dengan variabel motivasi (X4) sebagai intervening adalah sebesar $31.5 \%$. 2). kebijakan dalam mengambil keputusan (X2) berpengaruh secara positif dan signifikan terhadap kinerja (Y) dengan variable motivasi (X4) sebagai intervening adalah sebesar $21.8 \% .3$ ). kepribadian (X3) berpengaruh secara positif dan signifikan terhadap Kinerja (Y) dengan variabel motivasi (X4) sebagai intervening adalah sebesar $23 \%, 4)$ motivasi berpengaruh secara positif dan signifikan terhadap kinerja (Y) Hasil penelitian menunjukkan bahwa variabel perhatian terhadap bawahan (X1) paling dominan mempengaruhi kinerja karyawan dengan variabel intervening motivasi (X4). Oleh karena itu disarankan pada para pimpinan di STMIK Bahrul 'Ulum lebih memperhatikan para stafnya agar meningkatkan motivasi dan kinerjanya.

Kata kunci, Kepemimpinan, Motivasi dan Kinerja
\end{abstract}

\section{Pendahuluhan}

Peranan pimpinan untuk memotivasi kerja karyawan menjadi kewajiban yang harus dilakukan oleh pimpinan perusahaan. Pekerja harus mampu menangkap berbagai dorongan yang diberikan oleh perusahaan sehingga dapat memacu motivasi kerjanya disamping juga meningkatkan kemampuan kerjanya. Pada era persaingan yang sangat ketat diperlukan berbagai langkah dalam rangka efisiensi baik waktu mupun biaya, salah satunya adalah memaksimalkan sumber daya manusia. Disamping menghemat biaya dan waktu peningkatan kualitas sumber daya manusia adalah suatu investasi yang akan bermanfaat bagi perusahaan pada masa akan datang.

Kinerja (performance) adalah hasil kerja /produktivitas yang dicapai oleh seseorang pekerja atas dasar kemampuannya yang dapat diukur melalaui hasil yang telah dicapainya. Seseorang memiliki kinerja yang baik apabila hasil yang diperolehnya sesuai dengan rencana yang telah ditetapkan. Dalam bahasa manajemen untuk mengetahui dan mengevaluasi kinerja seseorang adalah menjadi tugas fungsi pengawasan (controlling). Kinerja (performance) karyawan dapat dioptimalkan melalui aktivitas-aktivitas yang dilakukan secara maksimal. Kepemimpinan yang diterapkan oleh atasan kepada bawahan dapat mempengaruhi motivasi dan kinerja karyawan pada suatu perusahaan. Pada penelitian ini akan dibahas mengenai kepemimpinan dan pengaruhnya terhadap motivasi dan kinerja karyawan STMIK bahrul 'Ulum.

Kinerja karyawan adalah merupakan hasil kerja yang bersangkutan baik dari segai kuantitas aupun kualitas berdasarkan standar kerja yang telah ditentukan. Untuk memperoleh kinerja karyawan seperti yang diharapkan diperlukan pengkajian baik secara teoritis maupun secara aplikatif terhadap faktor-faktor yang mempengaruhinya.

Berdasarkan latar belakang seperti tersebut di atas, dalam penelitian ini penulis mengambil judul "MANAJEMEN KEPEMIMPINAN SERTA KORELASINYA TERHADAP MOTIVASI DAN KINERJA KARYAWAN PADA STMIK BAHRUL 'ULUM TAMBAKBERAS JOMBANG”. 
Adanya pemahaman antara satu pihak dengan pihak lainnya, dalam hal ini pimpinan harus bisa memahami kepentingan karyawan, begitupun sebaliknya karyawan harus bisa memahami kepentingan pimpinan sehingga mendorong komunikasi yang efektif dan efisien, termasuk di dalamnya masalah kepemimpinan dan motivasi kerja yang kerap dipermasalahkan oleh bawahan sehingga menimbulkan berbagai persoalan.

\section{Metode Penelitian}

\section{Variabel Penelitian}

Variabel independen (varibel bebas) terdiri dari varibel utama yang meliputi perhatian terhadap bawahan (karyawan)(X1), kebijakan dalam mengambil keputusan (X2) dan sikap/kepribadian (X3) , varibel intervening (X4) adalah motivasi sedangkan varibel dependen (variable terikat) adalah kinerja karyawan (Y)

\section{Rancangan Analisis}

Data yang terkumpul kemudian di olah dan dianalisa secara inferensial maupun dengan menggunakan teknik statistic yaitu ;

\section{Analisis Jalur}

Sesuai dengan tujuan penelitian ini, metode analisis data yang digunakan adalah analisis jalur (path analysis). Analsis jalur bertujuan untuk menunjukkan akibat langsung dan tidak langsung seperangkat variable bebas terhadap variable terikatnya (Siregar, 2004;257).

\section{Model Regresi}

1. $\mathrm{Z}_{\mathrm{X} 4}=\beta_{\mathrm{ZX} 41 \mathrm{ZX} 1}+\beta_{\mathrm{ZX} 42 \mathrm{ZX} 2}+\beta_{\mathrm{ZX} 43 \mathrm{ZX} 3} \longrightarrow \mathbf{R}_{\mathbf{1}}{ }^{2}$

2. $Z_{\mathrm{Y}}=\beta_{\mathrm{ZY} 4 \mathrm{ZX} 4} \longrightarrow \mathbf{R}_{2}{ }^{2}$

Dimana : $\beta_{\mathrm{Zi}}=$ koefisien jalur

\section{Hasil dan Diskusi}

\section{Hasil Analisis}

\section{Analisis Regresi}

Dari hasil pengolahan data dengan menggunakan program SPSS versi 10.0 Release Window XP, maka diperoleh hasil-hasil yang dapat dilihat dalam tabel berikut :

Tabel 1. Hasil Analisis Variabel Independent

\begin{tabular}{|l|l|l|l|}
\hline \multicolumn{4}{|l|}{ Vriabel Independen $=$ X4 (Motivasi) } \\
\hline Variabel Independent & Koefisien Standart & T-hitung & Signifikan \\
\hline $\mathrm{X} 1$ & 0,459 & 3,507 & 0,001 \\
\hline $\mathrm{X} 2$ & 0,318 & 2,433 & 0,020 \\
\hline $\mathrm{X} 3$ & 0,335 & 2,561 & 0,015 \\
\hline Konstanta & 4,358 & & \\
\hline $\mathrm{R}_{1}{ }^{2}=0,419$ & F-stat $=8,190$ & \\
$\mathrm{R}=0,648$ & Sign $=0,00$ & \\
\hline
\end{tabular}

Tabel 2. Hasil Analisis Variabel Dependent

Vriabel dependen $=$ Y $($ Kinerja $)$ 


\begin{tabular}{|l|l|l|l|}
\hline Variabel Independent & Koefisien Standart & T-hitung & Signifikan \\
\hline $\mathrm{X} 4$ & 0,687 & 5,670 & 0,00 \\
\hline Konstanta & $-7,001$ & & \\
\hline $\mathrm{R}_{1}{ }^{2}=0,413$ & F-stat $=32,256$ & \\
$\mathrm{R}=0,678$ & DW_stat $=9,056$ & \\
\hline
\end{tabular}

Dari hasil analisis regresi sebagaimana yang terangkum dalam tabel diatas, pengaruh variabel independen yang terdiri dari perhatian terhadap bawahan (X1), kebijakan dalam mengambil keputusan (X2), Kepribadian (X3) dan Motivasi (X4) terhadap kinerja karyawan (Y) di STMIK Bahrul 'Ulum maka dapat disusun sebuah model persamaannya sebagai berikut :

a. $\mathrm{X} 4=0.459 \mathrm{X} 1+0.318 \mathrm{X} 2+0.335 \mathrm{X} 3$

$\mathrm{T}$ - hitung; $\mathrm{X} 1=3.507 ; \mathrm{X} 2=2.433 ; \mathrm{X} 3=2.561$

Signifikan; $\mathrm{X} 1=0.001 ; \mathrm{X} 2=0.020 ; \mathrm{X} 3=0.015$

$\mathrm{R}_{1}^{2}=0.419$

F. Statistik $=8.190$

b. $\mathrm{Y}=0.687 \mathrm{X} 4$

$\mathrm{T}-$ hitung; $\mathrm{X} 4=5.670$

Signifikan; $\mathrm{X} 4=0.000$

Dari model tersebut kemudian di interprestasikan ke dalam bentuk analisis sebagai berikut :

\section{Analisis Jalur}

a. Pengaruh tidak langsung $\mathrm{X} 1 \rightarrow \mathrm{X} 4 \rightarrow \mathrm{Y}=(0.459) *(0.687)=0.315$. Jadi pengaruh perhatian pimpinan pada bawahan (X1) terhadap Kinerja karyawan (Y) dengan variabel motivasi (X4) sebagai intervening adalah sebesar $31.5 \%$. Sehingga hipotesis pertama yang menyatakan bahwa variabel perhatian terhadap bawahan berpengaruh positif dan signifikan terhadap kinerja (Y) diterima

b. Pengaruh tidak langsung $\mathrm{X} 2 \rightarrow \mathrm{X} 4 \rightarrow \mathrm{Y}=(0.318) *(0.687)=0.218$.Jadi pengaruh kebijakan dalam mengambil keputusan (X2) terhadap Kinerja (Y) dengan variabel motivasi (X4) sebagai intervening adalah sebesar $21.8 \%$. Sehingga hipotesis kedua yang menyatakan bahwa kebijakan dalam mengambil keputusan berpengaruh positif dan signifikan terhadap kinerja (Y) diterima.

c. Pengaruh tidak langsung $\mathrm{X} 3 \rightarrow \mathrm{X} 4 \rightarrow \mathrm{Y}=(0.335) *(0.687)=0.23$. Jadi pengaruh kepribadian (X3) terhadap Kinerja (Y) dengan variabel motivasi (X4) sebagai intervening adalah sebesar $23 \%$. Sehingga hipotesis ketiga yang menyatakan bahwa kepribadian berpengaruh positif dan signifikan terhadap kinerja (Y) diterima

\section{Pengaruh Dominan}

Berdasarkan pengaruh tidak langsung (analisis jalur), maka dapat diketahui variabel yang mempunyai pengaruh dominan terhadap kinerja dalam hal ini adalah variabel perhatian terhadap bawahan yang dalam analisis regresi koefisien pengaruh tidak langsungnya sebesar $31.5 \%$. Prosentase tersebut lebih besar dibandingkan dengan koefisien vaiabel kebijakan dalam mengambil keputusan sebesar $21.8 \%$ dan kepribadian pimpinan sebesar $23 \%$.

\section{Uji Multikolinieritas}

Analisis ini untuk mengetahui ada tidaknya hubungan yang kuat antara sesama variabel bebas. Dalam penelitian ini metode yang digunakan adalah Pearson yaitu hubungan atau korelasi antar variabel . Dari hasil uji Pearson diketahui bahwa korelasi antara variabel X1 dengan X2 sebesar 0.051, $\mathrm{p}=0.761$, karena harga $\mathrm{p}>0.05$ maka tidak signifikan sehingga tidak terjadi 
multikolinearitas, sehingga asumsi tepenuhi. Korelasi antara variabel X1 dengan X3 sebesar 0.017, $\mathrm{p}=0.919$, karena harga $\mathrm{p}>0.05$ maka

tidak signifikan sehingga tidak terjadi multikolinieritas, sehingga asumsi terpenuhi. Korelasi antara varibel X2 dengan X3 sebesar 0.023, $\mathrm{p}=0.889$, karena harga $\mathrm{p}>0.05$ maka tidak signifikan sehingga tidak terjadi multikolinieritas, sehingga asumsi terpenuhi.

\section{Diskusi}

Dari hasil analisis regresi yang telah dilakukan dengan bantuan program SPSS dan pengujian hipotesis memberikan makna bahwa perhatian pimpinan terhadap bawahan (X1), dengan intervening motivasi (X4) mempunyai pengaruh yang positif dan signifikan terhadap kinerja karyawan (Y), kebijakan dalam mengambil keputusan (X2), dengan intervening motivasi (X4) mempunyai pengaruh yang positif dan signifikan terhadap kinerja karyawan (Y), kepribadian (X3), dengan intervening motivasi (X4) mempunyai pengaruh yang positif dan signifikan terhadap kinerja karyawan (Y) dan motivasi (X4) mempunyai pengaruh yang positif dan signifikan terhadap kinerja karyawan (Y). Hal tersebut tercermin dari besarnya nilai koefisien regresi. Angka tersebut sekaligus menggambarkan adanya kontribusi yang positif dan signifikan dari variabel bebas ( perhatian terhadap bawahan, kebijakan dalam mengambil keputusan, kepribadian dan motivasi) terhadap variabel tergantung (kinerja karyawan) dan kontribusi yang positif dan signifikan pula dari variabel intervening (motivasi) terhadap variabel tergantung (kinerja). Pada bagian ini akan dibahas hasil analisis inferensial, yaitu analisis jalur dengan menggunakan pendekatan teoritis, artinya hasil analisis inferensial digunakan sebagai petunjuk awal untuk menelusuri beberapa permasalahan dan fenomena.

Hasil penelitian menunjukkan bahwa variabel yang paling dominan mempengaruhi kinerja karyawan adalah varibel perhatian terhadap bawahan yaitu sebesar $31.5 \%$. Hal tersebut terjadi karena berdasarkan hasil kuesioner responden menjawab bahwa perhatian pimpinan terhadap bawahan adalah sangat baik yaitu sebesar $68.42 \%$.

Dengan pembahasan tersebut berarti dapat diungkapkan bahwa apabila seorang pimpinan memberikan perhatian yang baik terhadap stafnya maka dia akan merasa berhutang budi pada pimpinannya. Staf yang telah merasa berhutang budi atas perhatian yang diberikan pimpinannya tersebut akan membalasnya dengan meningkatkan motivasi kerjanya dan akhirnya kinerjanya akan lebih baik. Demikian

halnya untuk STMIK Bahrul 'Ulum hendaknya menerapkan hal tersebut sesuai dengan hasil penelitian yang telah penulis lakukan.

\section{Kesimpulan}

Berdasarkan hasil analisis statistik, pengujian hipotesis dan pembahasan dapat diambil kesimpulan sebagai berikut :

1. Kepemimpinan ( yang terdiri dari variable perhatian terhadap bawahan, kebijakan dalam mengambil keputusan dan kepribadian ) secara bersama-sama berpengaruh positif dan signifikan terhadap kinerja karyawan STMIK Bahrul 'Ulum dengan variabel intervening motivasi yang dibuktikan dengan besarnya nilai $\mathrm{F}$ hitung $=81.90$. Besarnya pengaruh dari kepemimpinan terhadap kinerja dengan variable intervening motivasi dapat dilihat dari besarnya nilai koefisien determinasi $(\mathrm{R} 2)$ sebesar $=0.419$. Besarnya angka tersebut memberikan makna bahwa besarnya tingkat kinerja karyawan sekitar 41.9 persennya ditentukan oleh perubahan variable kepemimpinan para pimpinan bagian.

2. Berdasarkan hasil analisis jalur terlihat bahwa pengaruh perhatian pimpinan pada bawahan (X1) terhadap kinerja (Y) dengan variabel motivasi (X4) sebagai intervening adalah sebesar 
31.5\%. Pengaruh kebijakan dalam mengambil keputusan (X2) terhadap kinerja (Y) dengan variable motivasi (X4) sebagai intervening adalah sebesar 21.8\%. Pengaruh kepribadian (X3) terhadap Kinerja (Y) dengan variabel motivasi (X4) sebagai intervening adalah sebesar $23 \%$.

\section{Daftar Pustaka}

Azwar Saifudin, 1986, Reliabilitas dan Validitas ,Edisi 1, Yogyakarta Liberty Bernadin, H.John \& Joyce E.A. Russell.,1993, Human Resource Management, International Edition, Singapura: McGraw Hill, Inc

Covey R., Stephen. Alih bahasa oleh Julius Sanjaya, 1997, Kepemimpinan Yang Berprinsip. Jakarta Bina Rupa Aksara

Danim, Sudarwan, 2004, Motivasi Kepemimpinan dan Efektivitas Kelompok. Jakarta: Penerbit Rineka Cipta

Dessler, Gary, 1984, Human Resources Management, : Pretince Hall, Inc. Istiningsih (2006) Pengaruh Kepemimpinan Terhadap Motivasi Dan Kinerja Karyawan Stmik Amikom Yogyakarta. Jurnal Ilmiah Manajerial 2(1), Hal: 10-55

Katz,D., Kahn, R.L (1978) The Social Psychology of organizations, 2nd ed. New York: John Wiley

Siregar Syafaruddin, 2004, Statistik Terapan untuk Penelitian,Jakarta : PT. Gramedia Widiasarana

Subagyo, Pangestu, 1998, Statistik Deskriptif. BPFE: Yogyakarta

Winardi, 2004, Motivasi dan Pemotivasian dalam Manajemen. Jakarta: PT. Raja Grafindo Persada.

Yukl, Gary, 1994, Kepemimpinan Dalam Organisasi Edisi Bahasa Indonesia. Jakarta:Prehallindo 